Keywords: Gloveboxes,

Polymers, Gloves,

Puncture

Retention: 25 yrs-10561

\title{
SRNL-STI-2012-00068
}

\section{Puncture Test Characterization of Glovebox Gloves}

\author{
P.S. Korinko \\ Y. Breakiron \\ G. K. Chapman
}

February 29, 2012

\section{We Put Science To Work"}

The Savannah River National Laboratory is managed and operated for the U.S. Department of Energy by

S A V A N N H RIVER N UCLEAR SOLUTIONS, LLC

AIKEN, SC USA $29808 \bullet$ SRNL.DOE.GOV 
This Page Intentionally Left Blank 


\section{SRNL-STI-2012-00068}

\section{Puncture Test Characterization of Glovebox Gloves}

Approvals:

Signature on file

$r$

2-28-2012

P. S. Korinko, Author

Materials Compatibility and Welding Technology

Signature on file

Y. Breakiron, Author

$3-5-2012$

Tritium Engineering Intern, Clemson University

Signature on file

G.R. Chapman, Author



Materials Compatibility and Welding Technology

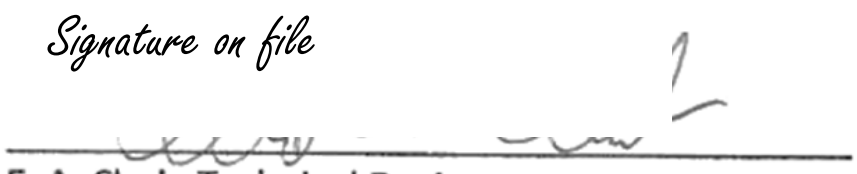

E. A. Clark, Technical Review

Materials Compatibility and Welding Technology

Signature on file

T. M. Adams, Manager

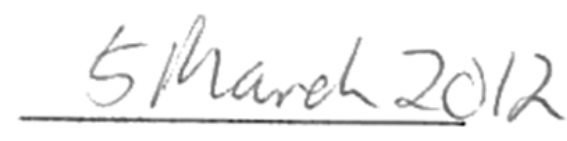

Materials Compatibility and Welding Technology

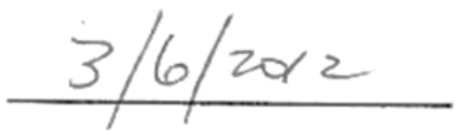




\section{Table of Contents}

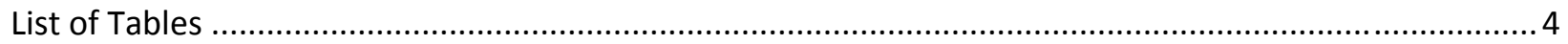

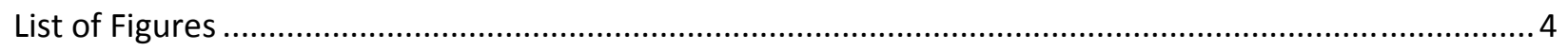

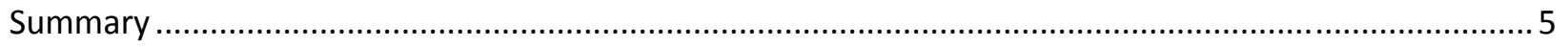

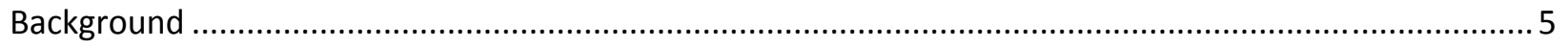

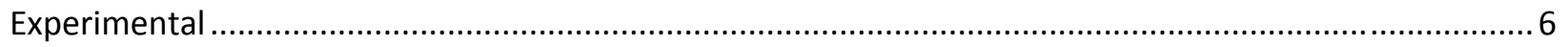



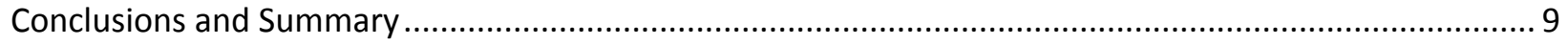

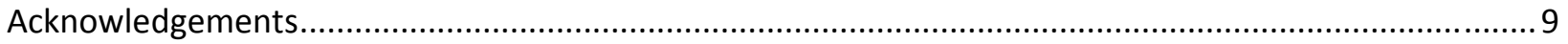

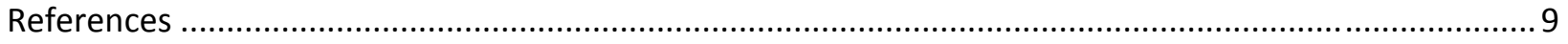

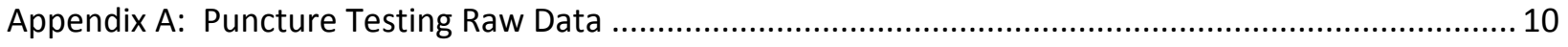

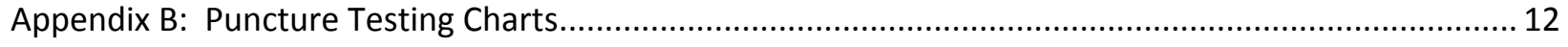

\section{List of Tables}

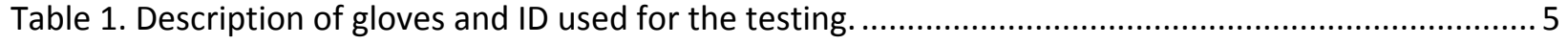

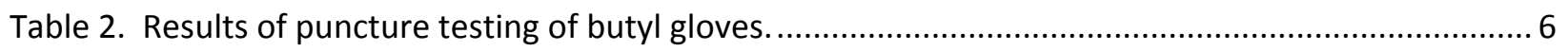

Table 3. Results for puncture testing other polymer gloves.............................................................. 8

\section{List of Figures}

Figure 1. Force-Extension plot for North 30 mil butyl. .................................................................... 7

Figure 2. Puncture resistance of Butyl gloves................................................................................ 7

Figure 3. Glove puncture resistance for other polymer gloves. ....................................................... 8

Figure 4. Load extension curve for Jung Butyl Viton............................................................................ 9 


\section{SRNL-STI-2012-00068}

\section{Puncture Test Characterization of Glovebox Gloves}

\section{Summary}

An experiment was conducted to determine the puncture resistance of 15 gloves that are used or proposed for use in the Tritium Facility at Savannah River Site (SRS). These data will serve as a baseline for characterization and may be incorporated into the glove procurement specification. The testing was conducted in agreement with ASTM D120 and all of the gloves met or exceeded the minimum requirements. Butyl gloves exhibited puncture resistance nearly 2.5 times the minimum requirements at SRS while Polyurethane was nearly $7.5 x$ the minimum.

\section{Background}

Currently butyl gloves are used in the facility because of their low permeability; however, butyl is not a particularly tough, puncture resistant, or abrasion resistant glove. To improve the physical and mechanical properties, the butyl gloves may be used with overgloves when exposed to wear applications. The Tritium Facility and SRS glovebox subject matter expert has been working with several vendors to characterize and improve the glove properties. Four vendors: North Piercan, Guardian and Jung, have supplied stock and experimental glove compositions and thicknesses for engineering evaluation. The gloves from these vendors, with the composition and nominal thickness listed in Table 1 have been tested for permeability, tensile, Thermogravimetric, Dynamic Mechanical Analysis and now puncture resistance. The results of the other characterizations are reported separately (1-4). A standard ASTM puncture test methodology (5) was used.

Table 1. Description of gloves and ID used for the testing.

\begin{tabular}{|c|c|c|c|c|c|c|c|}
\hline Vendor & Composition & $\begin{array}{l}\text { Thickness } \\
\text { (mils) }\end{array}$ & ID & Vendor & Composition & $\begin{array}{l}\text { Thickness } \\
\text { (mils) }\end{array}$ & ID \\
\hline North & Butyl & 15 & NB15 & North & Butyl & 30 & NB30 \\
\hline Piercan & Butyl & 15 & PB15 & Piercan & Butyl & 30 & PB30 \\
\hline Piercan & $\begin{array}{l}\text { Electrostatic } \\
\text { Discharge } \\
\text { Butyl }\end{array}$ & 15 & PESDB15 & Piercan & $\begin{array}{l}\text { Electrostatic } \\
\text { Discharge } \\
\text { Butyl }\end{array}$ & 24 & PESDB24 \\
\hline Guardian & Butyl & 15 & GB15 & Guardian & Butyl & 30 & GB30 \\
\hline Jung & $\begin{array}{l}\text { Butyl- } \\
\text { Hypalon }\end{array}$ & 27 & $\mathrm{JBH} 27$ & Jung & Butyl-Viton & 20 & JBV20 \\
\hline Jung & Viton & 24 & JV24 & Jung & Viton & 31 & JV31 \\
\hline Piercan & Polyurethane & 15 & PU15 & Piercan & $\begin{array}{l}\text { Polyurethane- } \\
\text { Hypalon }\end{array}$ & 20 & PUY20 \\
\hline Piercan & Hypalon ${ }^{\oplus}$ & 25 & PY25 & & & & \\
\hline
\end{tabular}




\section{Experimental}

Portions of ASTM D120 (5) were used as a guideline for this experiment. Disk samples were die cut from the hand portion of the glove to simulate the most likely scenario where a sharp will have the opportunity to penetrate a glove in the facility. The sample disk was mounted in a compression holder and probe A was driven into the sample at a cross head speed of $20 \mathrm{in} / \mathrm{min}$. A $200 \mathrm{lb}$ capacity load cell calibrated to ASTM E4 (6) was used for this experiment. The samples were tested to failure with an Instron Model 4507 test machine including a MTS Systems Renew Package. The load and deflection were recorded on a computer using Testworks software. The tests were completed in triplicate rather than 12 times due to time constraints.

\section{Results and Discussion}

The average results from the puncture test for butyl rubber gloves are listed in Table 2 and individual test data are listed in Appendix A. These results indicate an average puncture resistance of approximately $240 \mathrm{lbf} / \mathrm{in}$. This value exceeds the $100 \mathrm{lbf} /$ in referred to in ASTM D120 for electrical gloves (5). The data are presented graphically in Figure 2 . The standard deviation for the individual three tests is listed in the table; these values show a relative spread of less than $10 \%$ that helps justify testing in triplicate. A typical load extension curve for 30 mil North Butyl is shown in Figure 1; individual data plots for the other gloves are presented in Appendix B. All of the pure materials and the PUY samples exhibited similar behavior with monotonic increases in load with extension and a sharp drop in the load on penetration.

Table 2. Results of puncture testing of butyl gloves.

\begin{tabular}{|c|c|c|c|c|c|c|c|c|}
\hline \multicolumn{10}{|c|}{ Butyl Gloves Puncture } \\
\hline Glove & $\begin{array}{c}\text { NB15 } \\
\text { Ave. }\end{array}$ & $\begin{array}{c}\text { NB30 } \\
\text { Ave. }\end{array}$ & $\begin{array}{c}\text { GB15 } \\
\text { Ave. }\end{array}$ & $\begin{array}{c}\text { GB30 } \\
\text { Ave. }\end{array}$ & $\begin{array}{c}\text { PB15 } \\
\text { Ave. }\end{array}$ & $\begin{array}{c}\text { PB30 } \\
\text { Ave. }\end{array}$ & $\begin{array}{c}\text { PESDB15 } \\
\text { Ave. }\end{array}$ & $\begin{array}{c}\text { PESDB24 } \\
\text { Ave. }\end{array}$ \\
\hline Extension (in) & 0.64 & 0.65 & 0.55 & 0.55 & 0.66 & 0.60 & 0.49 & 0.53 \\
\hline Load (Ibf) & 5.1 & 8.9 & 6.2 & 8.6 & 4.5 & 11.4 & 4.3 & 5.9 \\
\hline Std Dev (Ibf) & 0.40 & 0.69 & 0.31 & 0.28 & 0.27 & 0.35 & 0.39 & 0.14 \\
\hline Thickness (in) & 0.023 & 0.038 & 0.023 & 0.034 & 0.025 & 0.038 & 0.020 & 0.025 \\
\hline Punct. Resist. (lbf/in) & 222 & 231 & 269 & 257 & 183 & 296 & 221 & 237 \\
\hline
\end{tabular}




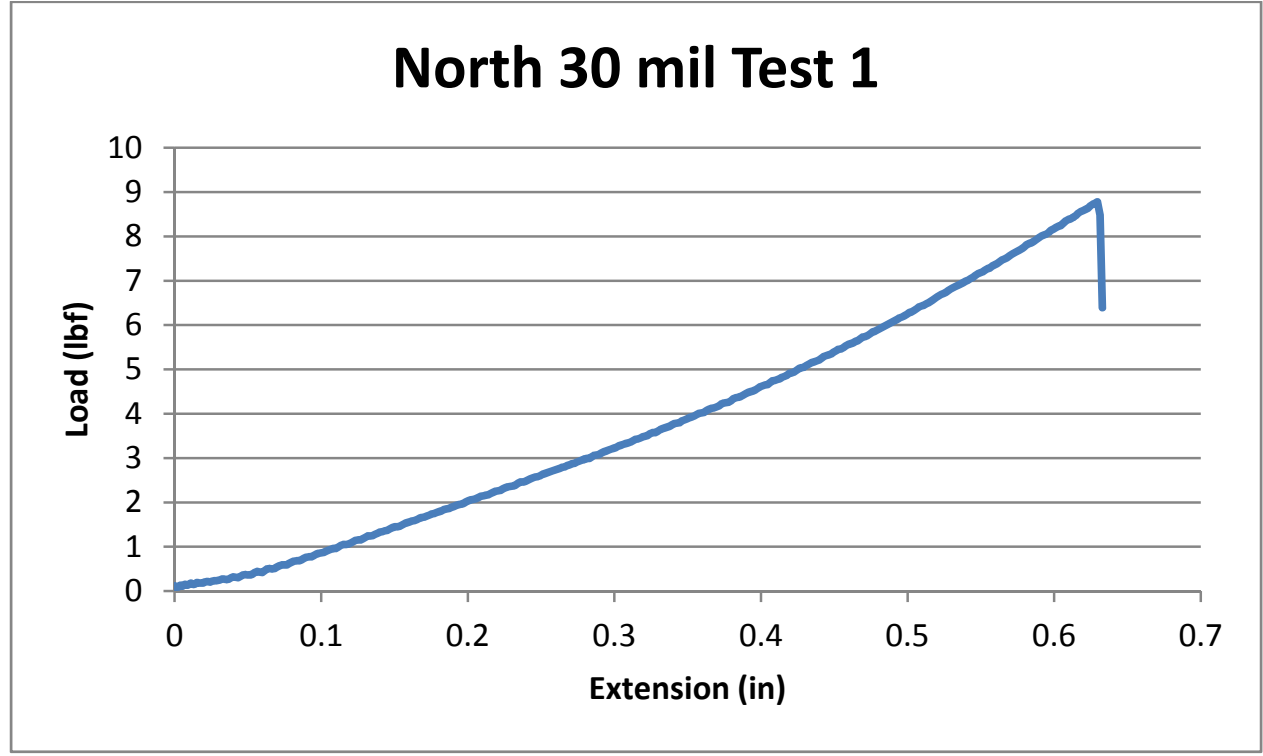

Figure 1. Force-Extension plot for North 30 mil butyl.

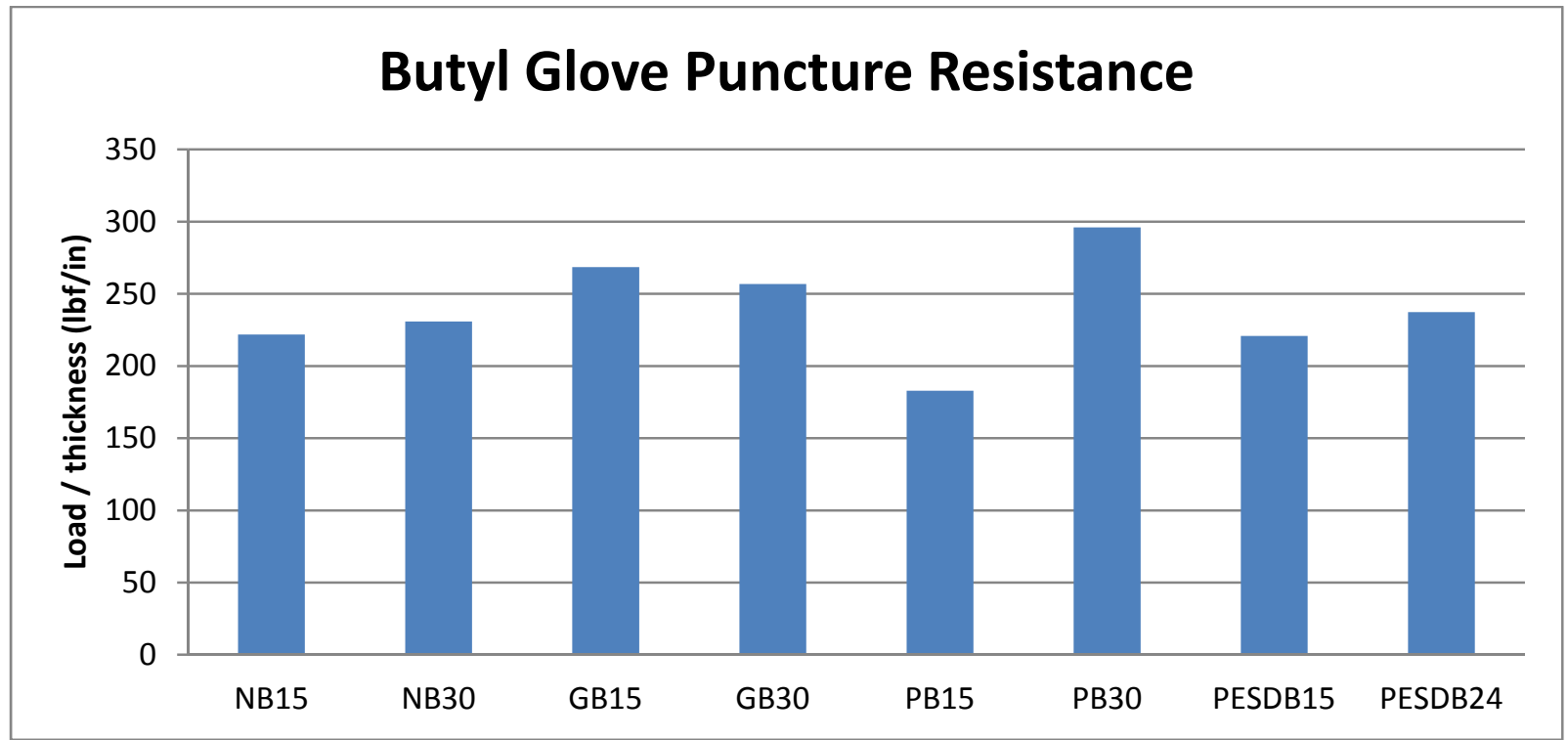

Figure 2. Puncture resistance of Butyl gloves.

The average results from the puncture test for other polymer gloves are listed in Table 3 and graphically in Figure 3. These results indicate a puncture resistance that exceeds $100 \mathrm{lbf} /$ in for all of the gloves that were tested, a minimum value for electrical gloves (5). As was the case for the butyl gloves, the standard deviation for the three tests is listed in the table, these values show a relative spread of less than $10 \%$.

All of the gloves exceed the minimum puncture resistance required for electrical gloves. The SRS specification does not explicitly require puncture testing, so these data are for information and comparison purposes only. The gloves can be ranked from highest to lowest puncture resistance: polyurethane, polyurethane-Hypalon ${ }^{\circledR}$, Hypalon ${ }^{\circledR}$, Butyl and Viton ${ }^{\circledR}$, Butyl-Hypalon ${ }^{\circledR}$ and finally Butyl- 
Viton . The elongation to failure is another indicator of puncture resistance and a similar ranking occurs from this assessment as well.

Table 3. Results for puncture testing other polymer gloves.

\begin{tabular}{|c|c|c|c|c|c|c|c|}
\hline \multicolumn{8}{|c|}{ Other Polymer Gloves Puncture } \\
\hline Glove & $\begin{array}{c}\text { PU15 } \\
\text { Ave. }\end{array}$ & $\begin{array}{c}\text { PY25 } \\
\text { Ave. }\end{array}$ & $\begin{array}{c}\text { PUY20 } \\
\text { Ave }\end{array}$ & $\begin{array}{c}\text { JV24 } \\
\text { Ave. }\end{array}$ & $\begin{array}{c}\text { JV31 } \\
\text { Ave. }\end{array}$ & $\begin{array}{c}\text { JBV20 } \\
\text { Ave }\end{array}$ & $\begin{array}{c}\text { JBH27.5 } \\
\text { Ave. }\end{array}$ \\
\hline Extension (in) & 0.83 & 0.61 & 0.74 & 0.36 & 0.40 & 0.25 & 0.31 \\
\hline Load (Ibf) & 14.01 & 9.4 & 16.3 & 5.9 & 8.5 & 2.5 & 5.1 \\
\hline Thickness (in) & 0.019 & 0.023 & 0.023 & 0.027 & 0.044 & 0.022 & 0.035 \\
\hline Std Dev (lbf) & 0.97 & 0.35 & 1.46 & 0.51 & 0.24 & 0.18 & 0.11 \\
\hline $\begin{array}{c}\text { Punct. Resist. } \\
\text { (Ibf/in) }\end{array}$ & 749 & 408 & 697 & 215 & 191 & 115 & 146 \\
\hline
\end{tabular}

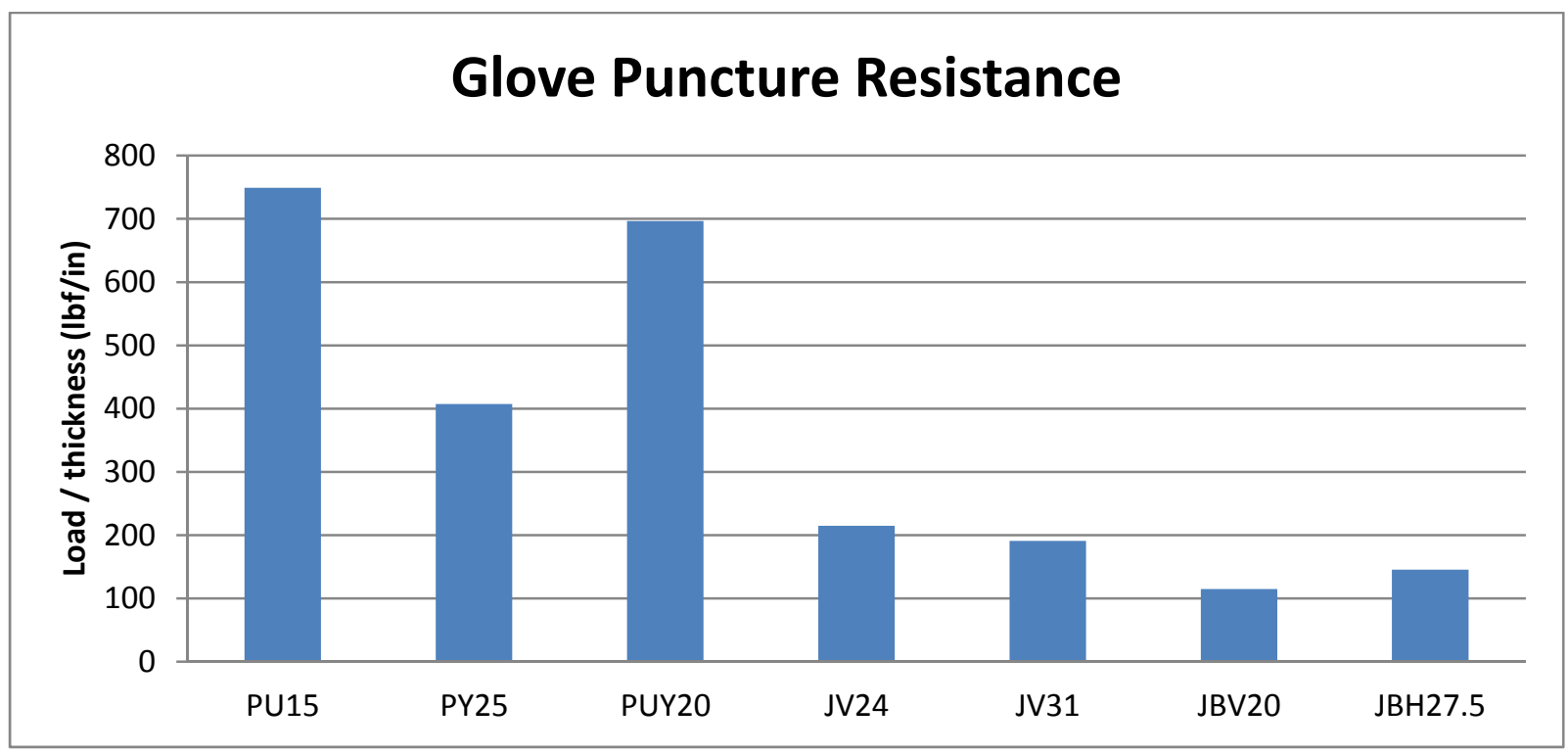

Figure 3. Glove puncture resistance for other polymer gloves.

Figure 4 shows the puncture test data from the Jung butyl-Viton test. This curve indicates that there were two failure events, with a partial unloading at about 0.18 inch and a complete failure at 0.25 inch extension. These discontinuities are attributed to the butyl failure followed by the Viton failure. Similar behavior was not observed for the other two layer gloves. The reason for either behavior was not pursued further. 


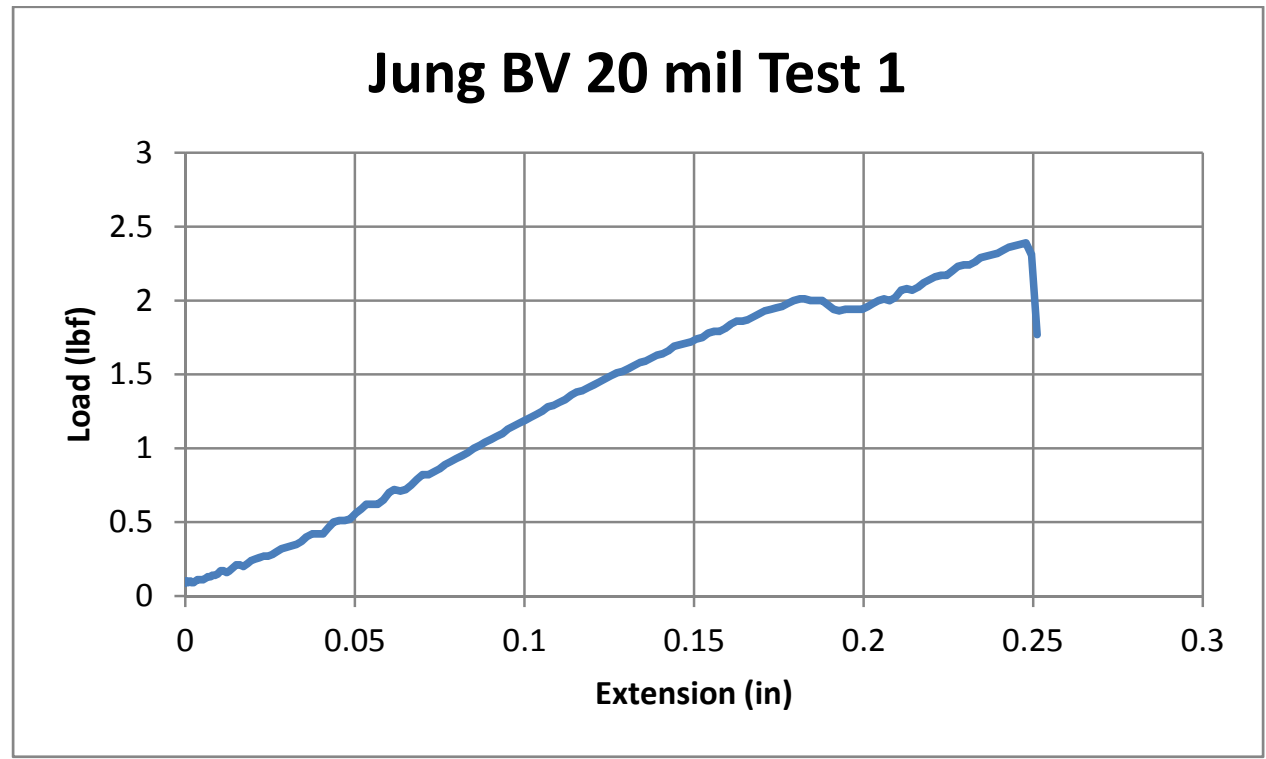

Figure 4. Load extension curve for Jung Butyl Viton.

\section{Conclusions and Summary}

All of the gloves meet or exceed the $100 \mathrm{lbf} /$ in requirement stated in ASTM D120 for electrical gloves. The Butyl gloves exhibit puncture resistance in excess of $200 \mathrm{lbf} / \mathrm{in}$ and the Polyurethane gloves exhibit the highest puncture resistance with a value of nearly $750 \mathrm{lbf} /$ in. Jung Butyl Viton glove failed in two stage manner with the lowest puncture resistance.

\section{Acknowledgements}

The authors would like to thank Tritium Operations, Tritium Engineering, and Tritium Extraction Facility for technical and financial support.

\section{References}

1. SRNL-STI-2012-00030, Thermogravimetric Characterization of Glovebox Gloves, P.S. Korinko, Y. Breakiron, Feb 29, 2012

2. SRNL-STI-2012-00069, Characterization of Tensile Strength of Glovebox Gloves , P.S. Korinko, Y. Breakiron, G. K. Chapman, Feb 29, 2012

3. SRNL-STI-2012-00030, Evaluation of Glovebox Gloves for Effective Permeation Control, P.S. Korinko, Y. Breakiron, Feb 29, 2012

4. SRNL-STI-2012-00070, Dynamic Mechanical Analysis Characterization of Glovebox Gloves, P.S. Korinko, Y. Breakiron, Feb 29, 2012

5. ASTM D120-09, Standard Specification for Rubber Insulating Gloves, West Conshohocken, PA 19428, 2009.

6. ASTM E4-10, Standard Practices for Force Verification of Testing Machines, West Conshohocken, PA 19428, 2010. 
Appendix A: Puncture Testing Raw Data

\begin{tabular}{|l|c|c|c|c|c|c|c|c|}
\hline Glove & NB15-1P & NB15-2P & NB15-3P & $\begin{array}{c}\text { NB15 } \\
\text { Ave. }\end{array}$ & NB30-1P & NB30-2P & $\begin{array}{c}\text { NB30- } \\
\text { 3P }\end{array}$ & $\begin{array}{c}\text { NB30 } \\
\text { Ave. }\end{array}$ \\
\hline Extension (in) & 0.63 & 0.64 & 0.66 & 0.64 & 0.63 & 0.70 & 0.63 & 0.65 \\
\hline Load (Ibf) & 4.85 & 5.59 & 4.98 & 5.14 & 8.78 & 9.61 & 8.23 & 8.87 \\
\hline Thickness & 0.023 & 0.023 & 0.023 & 0.023 & 0.038 & 0.038 & 0.038 & 0.038 \\
\hline P/t (Ibf/in) & 209 & 241 & 215 & 222 & 228 & 250 & 214 & 231 \\
\hline
\end{tabular}

\begin{tabular}{|l|c|c|c|c|c|c|c|c|}
\hline & GB15-1P & GB15-2P & GB15-3P & $\begin{array}{c}\text { GB15 } \\
\text { Ave. }\end{array}$ & GB30-1P & GB30-2P & $\begin{array}{c}\text { GB30- } \\
\text { 3P }\end{array}$ & $\begin{array}{c}\text { GB30 } \\
\text { Ave. }\end{array}$ \\
\hline Extension (in) & 0.55 & 0.54 & 0.56 & 0.55 & 0.56 & 0.55 & 0.54 & 0.55 \\
\hline Load (Ibf) & 6.55 & 6.14 & 5.94 & 6.21 & 8.50 & 8.93 & 8.41 & 8.61 \\
\hline Thickness & 0.023 & 0.023 & 0.023 & 0.023 & 0.034 & 0.034 & 0.034 & 0.034 \\
\hline P/t (Ibf/in) & 283 & 266 & 257 & 269 & 253 & 266 & 251 & 257 \\
\hline
\end{tabular}

\begin{tabular}{|l|c|c|c|c|c|c|c|c|}
\hline Glove & PB15-1P & PB15-2P & PB15-3P & PB15 Ave. & PB30-1P & PB30-2P & PB30-3P & $\begin{array}{c}\text { PB30 } \\
\text { Ave. }\end{array}$ \\
\hline Extension (in) & 0.63 & 0.68 & 0.67 & 0.66 & 0.59 & 0.60 & 0.61 & 0.60 \\
\hline Load (Ibf) & 4.35 & 4.83 & 4.39 & 4.52 & 10.97 & 11.45 & 11.64 & 11.35 \\
\hline Thickness & 0.025 & 0.025 & 0.025 & 0.025 & 0.038 & 0.038 & 0.038 & 0.038 \\
\hline P/t (lbf/in) & 176 & 195 & 178 & 183 & 286 & 299 & 304 & 296 \\
\hline
\end{tabular}

\begin{tabular}{|l|c|c|c|c|c|c|c|c|}
\hline Glove & $\begin{array}{c}\text { PESDB15- } \\
\text { 1P }\end{array}$ & $\begin{array}{c}\text { PESDB15- } \\
\text { 2P }\end{array}$ & $\begin{array}{c}\text { PESDB15- } \\
\text { 3P }\end{array}$ & $\begin{array}{c}\text { PESDB15 } \\
\text { Ave. }\end{array}$ & $\begin{array}{c}\text { PESDB24- } \\
\text { 1P }\end{array}$ & $\begin{array}{c}\text { PESDB24- } \\
\text { 2P }\end{array}$ & $\begin{array}{c}\text { PESDB24- } \\
\text { 3P }\end{array}$ & $\begin{array}{c}\text { PESDB24 } \\
\text { Ave. }\end{array}$ \\
\hline $\begin{array}{l}\text { Extension } \\
\text { (in) }\end{array}$ & 0.48 & 0.50 & 0.50 & 0.49 & 0.54 & 0.51 & 0.53 & 0.53 \\
\hline Load (Ibf) & 3.95 & 4.72 & 4.33 & 4.33 & 6.03 & 5.79 & 5.77 & 5.86 \\
\hline Thickness & 0.020 & 0.020 & 0.020 & 0.020 & 0.025 & 0.025 & 0.025 & 0.025 \\
\hline $\begin{array}{l}\text { P/t } \\
\text { (Ibf/in) }\end{array}$ & 201 & 241 & 221 & 221 & 244 & 234 & 234 & 237 \\
\hline
\end{tabular}

\begin{tabular}{|l|c|c|c|c|c|c|c|c|}
\hline Glove & JV24-1P & JV24-2P & JV24-3P & JV24 Ave. & JV31-1P & JV31-2P & JV31-3P & JV31 Ave. \\
\hline Extension (in) & 0.39 & 0.35 & 0.34 & 0.36 & 0.39 & 0.40 & 0.41 & 0.40 \\
\hline Load (Ibf) & 6.41 & 5.76 & 5.40 & 5.86 & 8.17 & 8.62 & 8.56 & 8.45 \\
\hline Thickness & 0.027 & 0.027 & 0.027 & 0.027 & 0.044 & 0.044 & 0.044 & 0.044 \\
\hline P/t (lbf/in) & 235 & 211 & 198 & 215 & 185 & 195 & 194 & 191 \\
\hline
\end{tabular}




\begin{tabular}{|l|c|c|c|c|c|c|c|c|c|}
\hline Glove & $\begin{array}{c}\text { PU15- } \\
\text { 1P }\end{array}$ & PU15-2P & $\begin{array}{c}\text { PU15- } \\
\text { 3P }\end{array}$ & $\begin{array}{c}\text { PU15- } \\
\text { 4P }\end{array}$ & $\begin{array}{c}\text { PU15 } \\
\text { Ave. }\end{array}$ & PY25-1P & PY25-2P & $\begin{array}{c}\text { PY25- } \\
\text { 3P }\end{array}$ & $\begin{array}{c}\text { PY25 } \\
\text { Ave. }\end{array}$ \\
\hline Extension (in) & 0.75 & 0.80 & 0.87 & 0.83 & 0.83 & 0.62 & 0.59 & 0.64 & 0.61 \\
\hline Load (Ibf) & 12.04 & 13.22 & 15.09 & 13.72 & 14.01 & 9.46 & 9.04 & 9.74 & 9.41 \\
\hline Thickness & 0.019 & 0.019 & 0.019 & 0.019 & 0.019 & 0.023 & 0.023 & 0.023 & 0.023 \\
\hline P/t (lbf/in) & 644 & 707 & 807 & 734 & 749 & 410 & 391 & 422 & 408 \\
\hline
\end{tabular}

\begin{tabular}{|l|c|c|c|c|c|c|c|c|}
\hline Glove & $\begin{array}{c}\text { JBV20- } \\
\text { 1P }\end{array}$ & $\begin{array}{c}\text { JBV20- } \\
\text { 2P }\end{array}$ & $\begin{array}{c}\text { JBV20- } \\
\text { 3P }\end{array}$ & $\begin{array}{c}\text { JBV20 } \\
\text { Ave }\end{array}$ & $\begin{array}{c}\text { JBH27.5- } \\
\text { 1P }\end{array}$ & $\begin{array}{c}\text { JBH27.5- } \\
\text { 2P }\end{array}$ & $\begin{array}{c}\text { JBH27.5- } \\
\text { 3P }\end{array}$ & $\begin{array}{c}J B H 27.5 \\
\text { Ave. }\end{array}$ \\
\hline Extension (in) & 0.25 & 0.24 & 0.27 & 0.25 & 0.31 & 0.30 & 0.31 & 0.31 \\
\hline Load (Ibf) & 2.39 & 2.44 & 2.72 & 2.52 & 5.20 & 5.21 & 5.02 & 5.14 \\
\hline Thickness & 0.022 & 0.022 & 0.022 & 0.022 & 0.035 & 0.035 & 0.035 & 0.035 \\
\hline $\mathrm{P} / \mathrm{t}$ (Ibf/in) & 109 & 112 & 124 & 115 & 147 & 147 & 142 & 146 \\
\hline
\end{tabular}

\begin{tabular}{|l|c|c|c|c|}
\hline Glove & PUY20-1P & PUY20-2P & PUY20-3P & PUY20 Ave \\
\hline Extension (in) & 0.71 & 0.76 & 0.75 & 0.74 \\
\hline Load (Ibf) & 14.68 & 16.65 & 17.53 & 16.29 \\
\hline Thickness & 0.023 & 0.023 & 0.023 & 0.023 \\
\hline P/t (Ibf/in) & 628 & 712 & 750 & 697 \\
\hline
\end{tabular}


Appendix B: Puncture Testing Charts
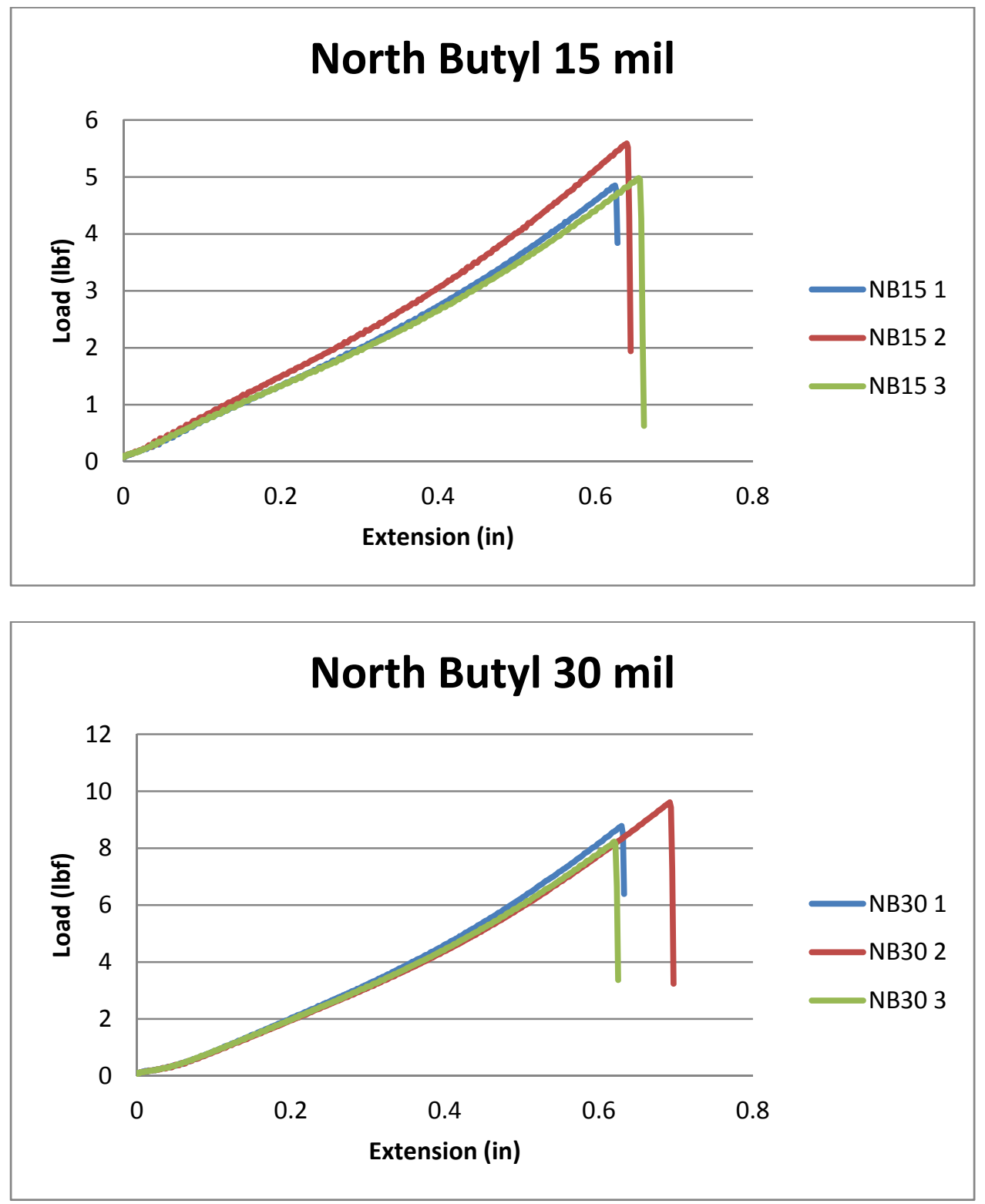

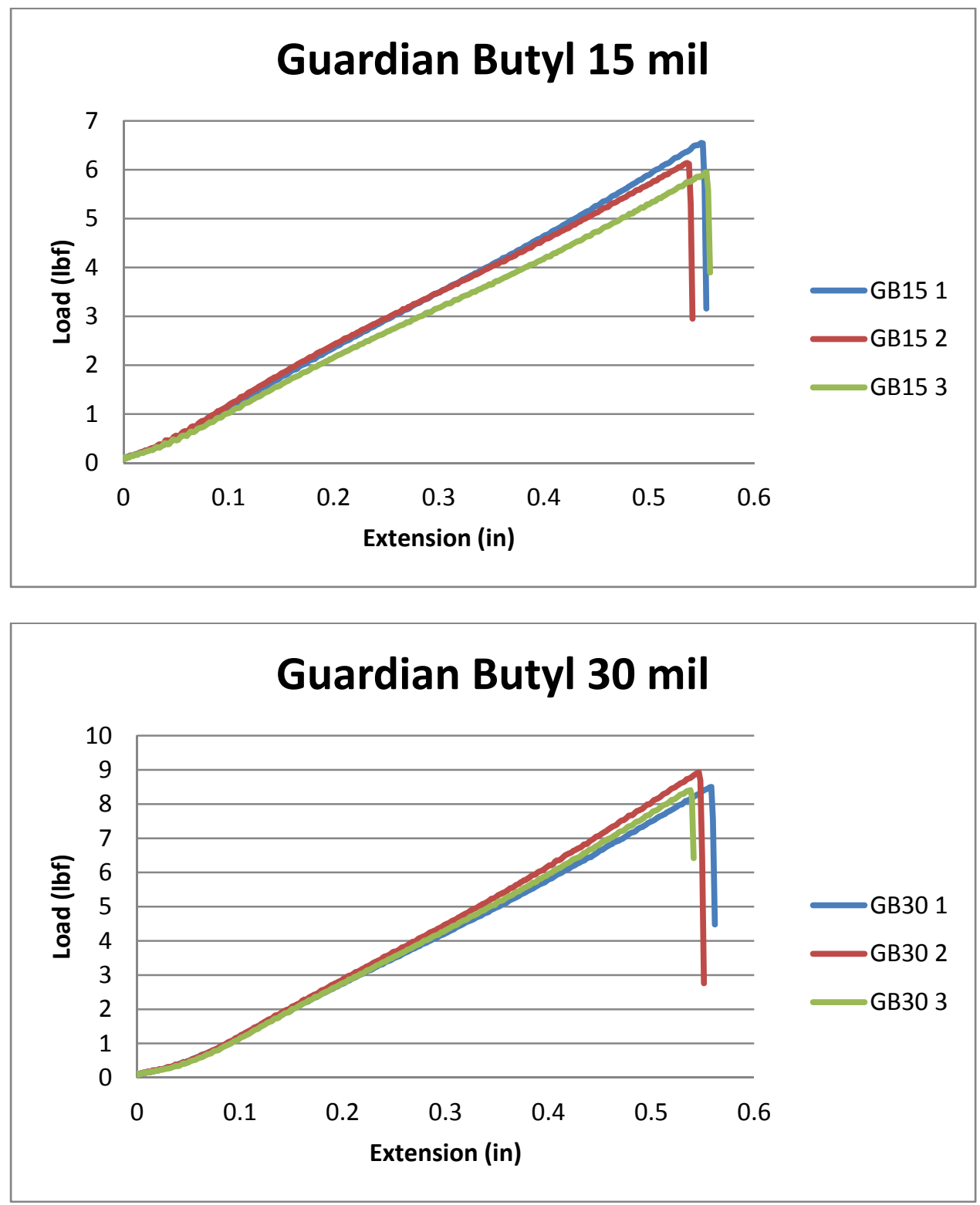

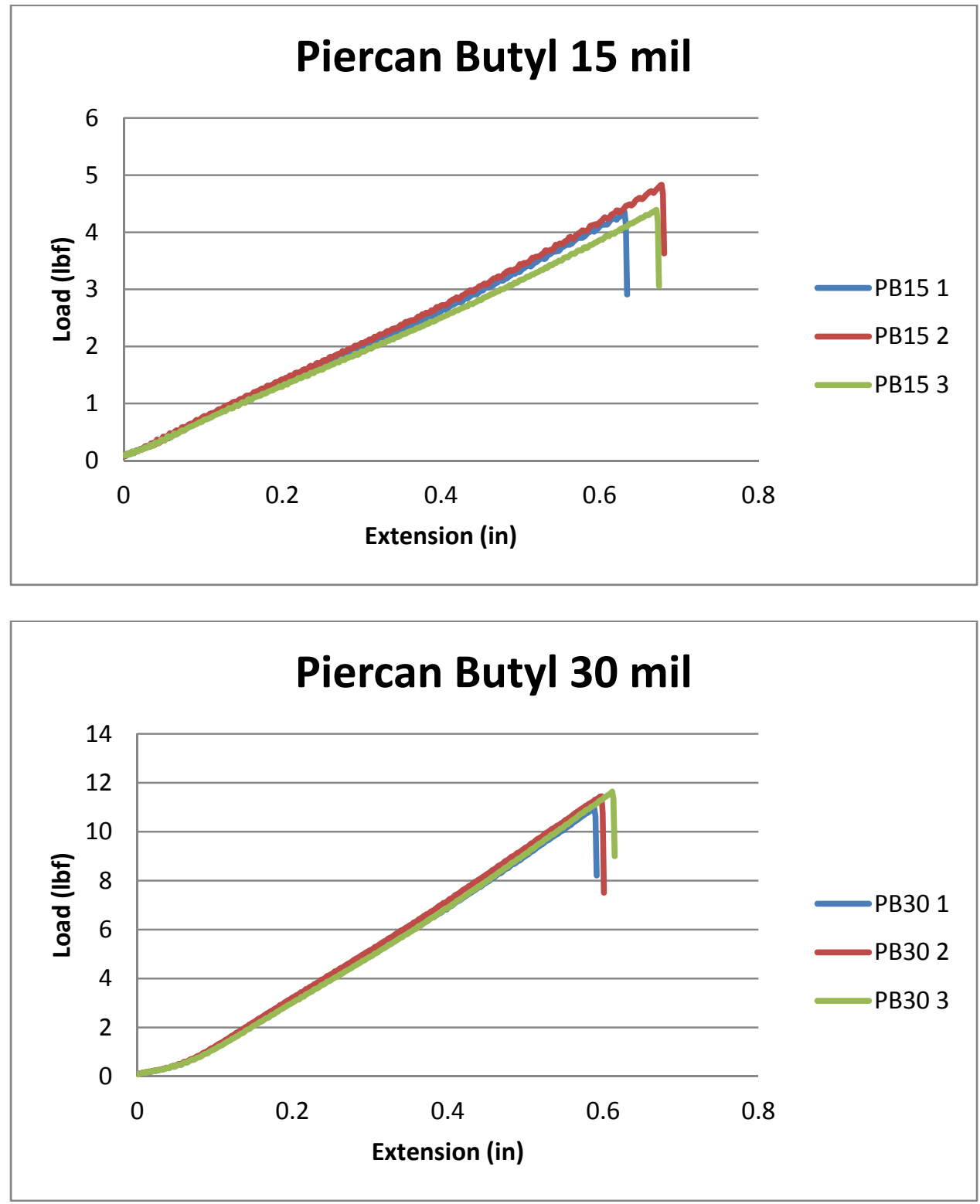

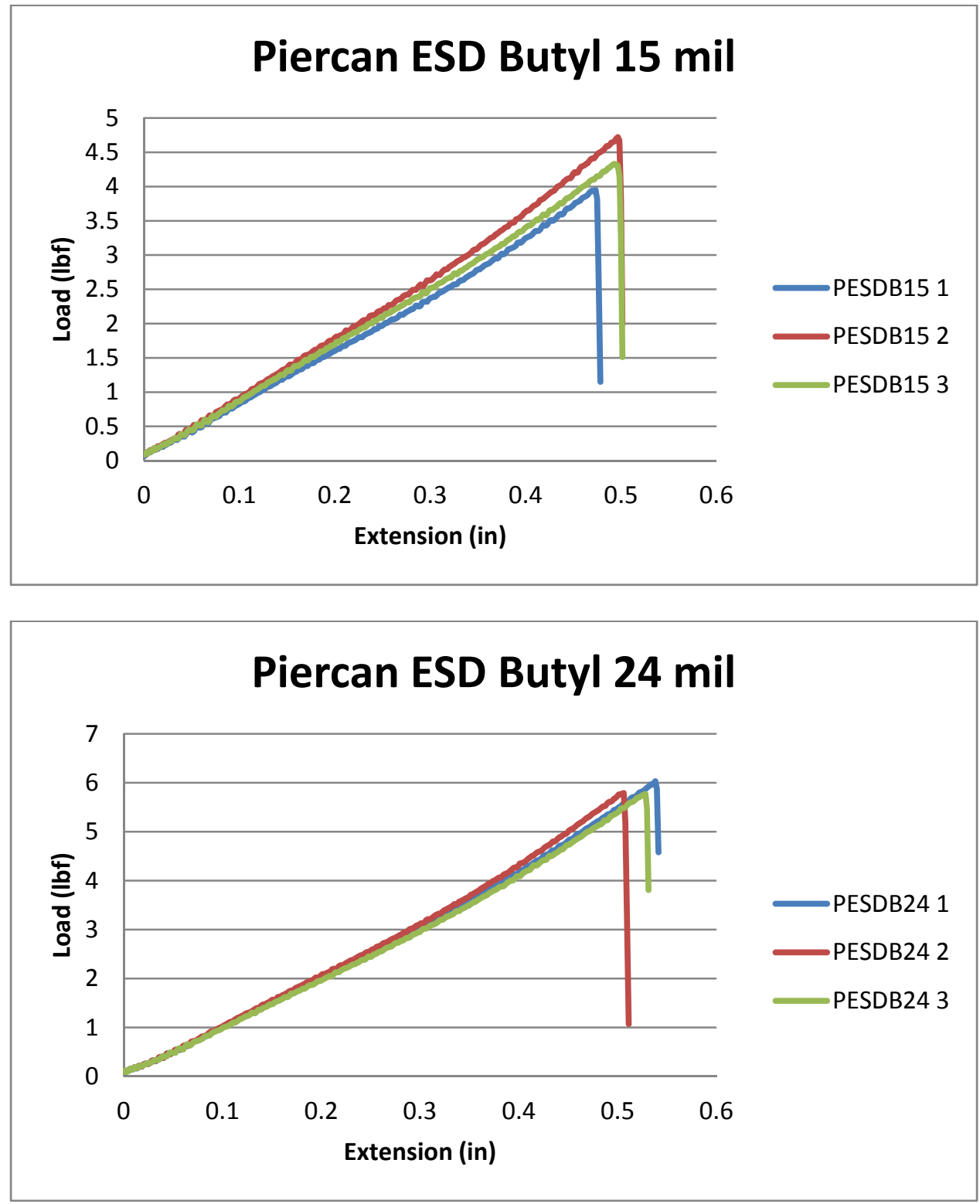

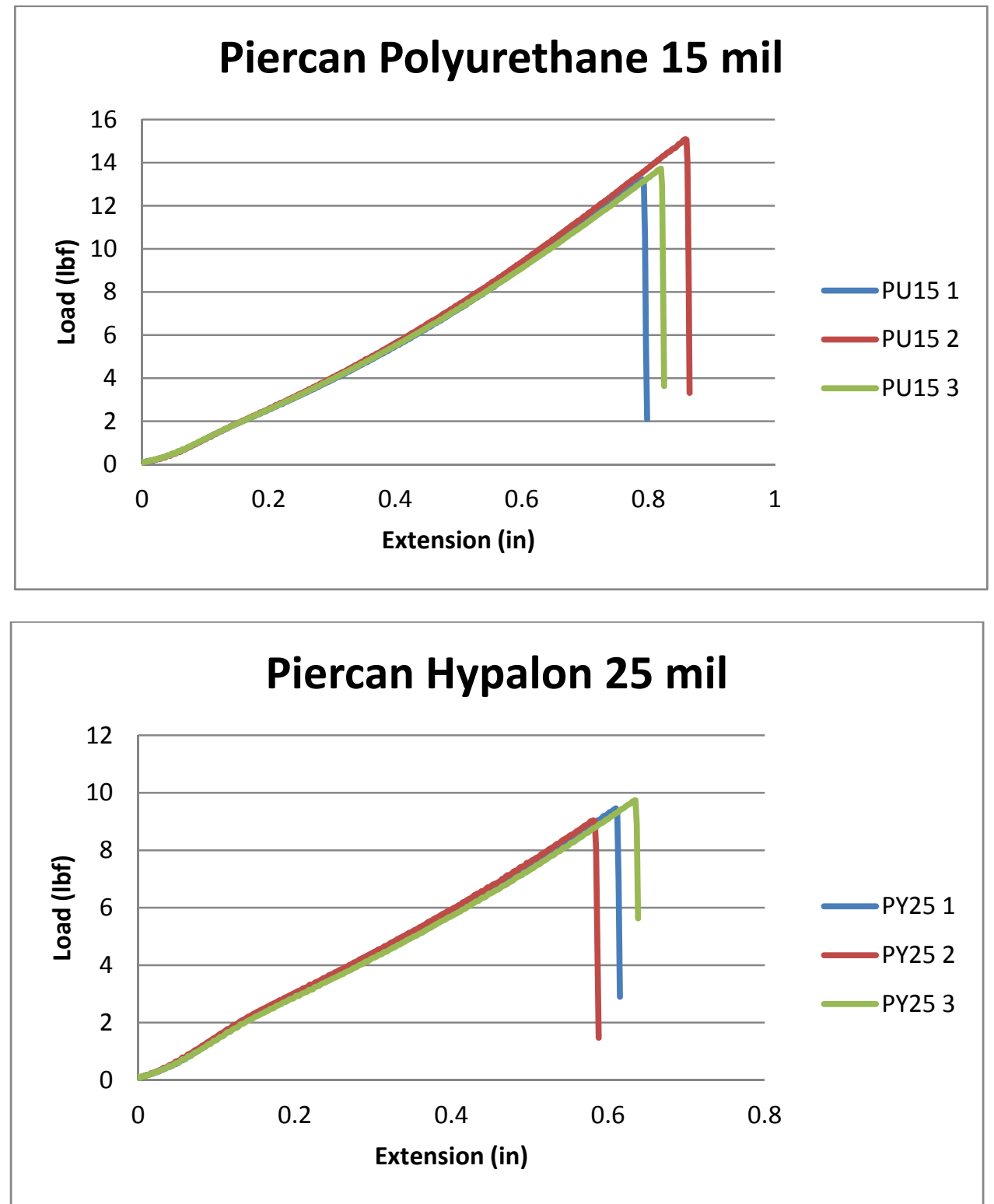


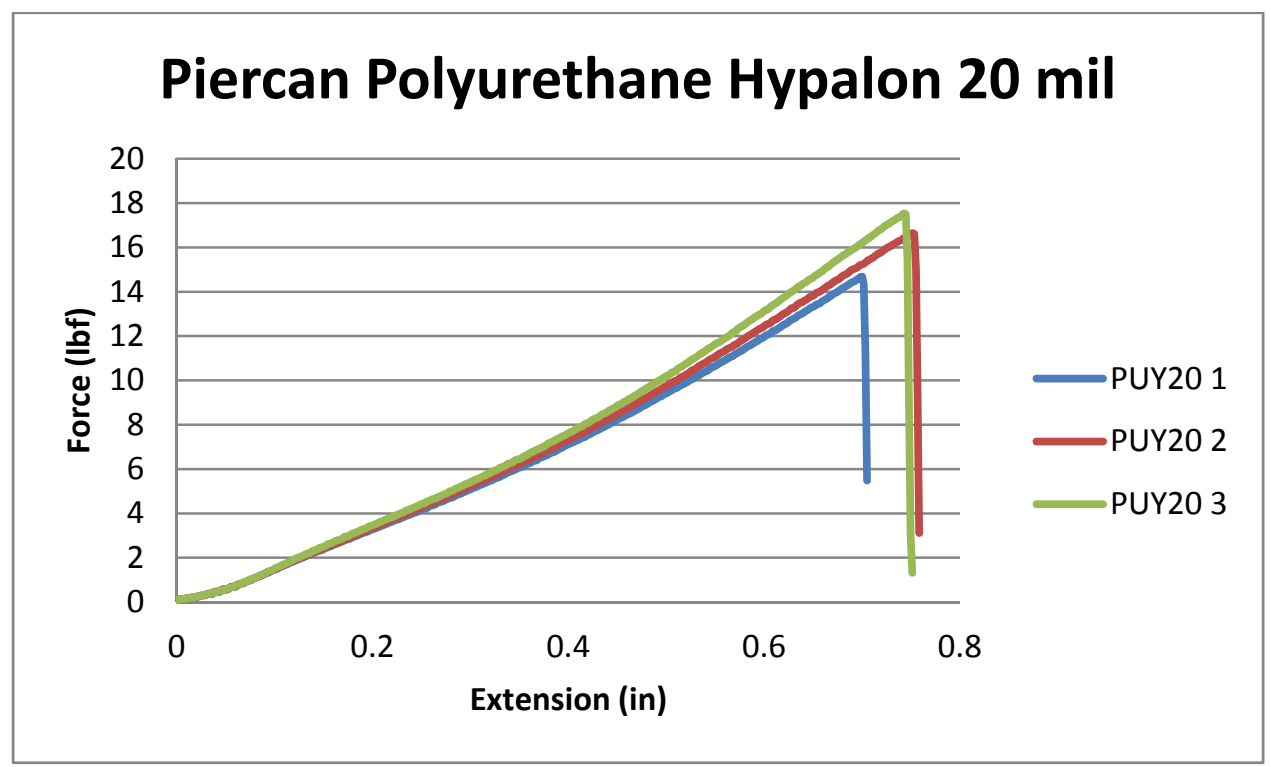





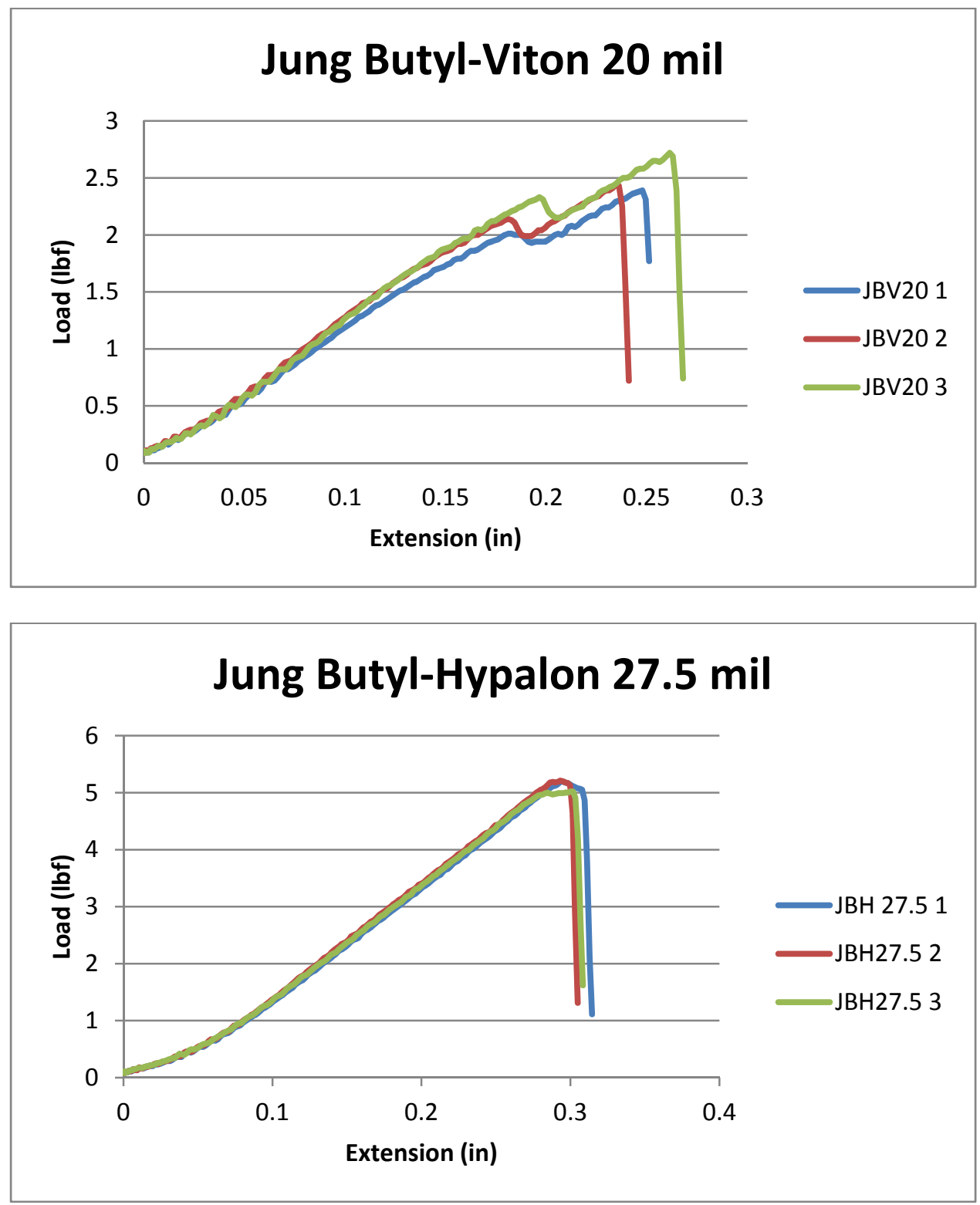